\title{
Tanggung Jawab Perusahaan Pengangkut DHL Express Terhadap Pengiriman Barang dari Jakarta ke Malang ( Studi Putusan Pengadilan Nomor 733/Pdt.G/2017/PN.JKT.SEL.)
}

\author{
Oleh: \\ Chriesty Angeline \\ (Mahasiswa Program S1 Fakultas Hukum Universitas Tarumanagara) \\ (E-mail: chriestyangelinegmail.com)
}

\section{Siti Nurbaiti}

(Corresponding Author)

(Dosen Fakultas Hukum Universitas Tarumanagara. Meraih Gelar Sarjana Hukum di Universitas Trisakti, Sarjana Sastra jurusan Arkeologi di Universitas Indonesia, Magister Hukum Bisnis di Fakultas Hukum Universitas Tarumanagara, dan Doktor Ilmu Hukum di Universitas Trisakti)

$$
\text { (E-mail: nurbaiti_05092000@yahoo.com) }
$$

\footnotetext{
Abstract:

In a transportation agreement, practice the rights and obligations of the parties are not always fulfilled, because during the process of shipping, sometimes it does not always went well, even there is the package disappearance cases. For example, a case that occurred between the DHL Express transport company and the sender Massayu Chairani who was disadvantage due to the loss of her package that the company agreed to delivered. How the company DHL Express responsibility of the shipping to the sender in transportation from Jakarta to Malang and How the District Court Decision Number 733 / Pdt.G / 2017 / PN.JKT.SEL regarding the responsibility of the shipping company DHL Express to the sender in transportation from Jakarta to Malang continue to make a discussion. The research method used is descriptive normative legal research method, using secondary data and primary data as supporting data with the law approach. The results of research illustrate that DHL Express does not give full responsibility to the sender and the results of judges' decisions that do not grant full compensation claims are also considered not in accordance with Article 91 KUHD and Law Number 22 of 2009 concerning Road Traffic and Transportation in Article 188 and Article 193 paragraph (1). It is recommended that DHL Express give full responsibility to the sender of the goods for transporting goods from Jakarta to Malang and should have a court decision can decide the case more carefully to grant full compensation claims.

Keywords: Responsibilities, Freight Agreement, DHL Express
} 


\section{PENDAHULUAN}

\section{A. Latar Belakang}

Pada Zaman modern ini transportasi adalah sarana yang dibutuhkan oleh banyak orang sejak zaman dahulu dalam melaksanakan kegiatannya dapat diwujudkan dalam bentuk pengangkutan. Pengangkutan artinya adalah mengangkut, Mengangkut artinya mengangkat dan membawa, memuat dan membawa atau mengirimkan. ${ }^{1}$

Menurut Soegijatna Tjakranegara, pengangkutan adalah memindahkan barang atau commodity of goods dan penumpang dari suatu tempat ketempat lain, sehingga pengangkut menghasilkan jasa angkutan atau produksi jasa bagi masyarakat yang membutuhkan untuk pemindahan atau pengiriman barang barangnya. ${ }^{2}$

Pengangkutan secara garis besar adalah perpindahan tempat, baik mengenai benda - benda maupun orang - orang , karena perpindahan itu mutlak diperlukan untuk mencapai dan meninggikan manfaat serta efisiensi. ${ }^{3}$ Sedangkan pengangkutan menurut Undang Undang Nomor 22 Tahun 2009 tentang Lalu Lintas dan Angkutan Jalan (“UU LLAJ”) pada pasal (1) angka (3) yaitu pengangkutan merupakan perpindahan orang dan atau barang dari satu tempat ke tempat yang lain dengan menggunakan kendaraan. ${ }^{4}$

Pengangkutan terbagi dalam dua hal, yaitu pengangkutan orang dan barang yang peruntukannya untuk umum atau pribadi. Istilah

\footnotetext{
${ }^{1}$ Abdul Kadir Muhammad, Hukum Pengangkutan Darat, Laut, dan Udara, (Bandung: PT. Citra Aditya Bakti 1991), hal. 19.

${ }^{2}$ Soegijatna Tjakranegara, Hukum Pengangkutan Barang dan Penumpang, (Jakarta, PT. Rineka Cipta, 1995), hal.1.

3 Sution Usman Adji, Hukum pengangkutan indonesia, (Jakarta:PT Rinka Cipta, 1990),hal.1.

${ }^{4}$ Undang-Undang Nomor 22 Tahun 2009 tentang Lalu Lintas dan Angkutan Jalan, Pasal. 1 Angka. 3.
} 
"Pengangkutan" berasal dari kata "angkut" yang berarti "mengangkut dan membawa", sedangkan istilah "pengangkutan" dapat diartikan sebagai "pembawaan barang-barang atau orang-orang". Dalam setiap perjanjian pengangkutan akan selalu diawali dengan suatu kesepakatan antara pihak pengangkut dengan pihak penumpang ataupun pengirim. Pada dasarnya dalam suatu kesepakatan akan berisi mengenai kewajiban dan hak pihak pengangkut serta hak dan kewajiban pihak penumpang ataupun pengirim. Dalam kesepakatan perjanjian pengangkutan kewajiban pengangkut adalah untuk mengangkut penumpang atau barang dari suatu tempat keberangkatan sampai pada tempat tujuan yang telah disepakati dalam keadaan selamat. Sebagai bentuk timbal baliknya, hak - hak pengangkut adalah menerima sejumlah uang sebagai imbalan biaya angkut atau uang sewa atau dikenal juga sebagai biaya angkut, sedangkan kewajiban pengirim barang adalah untuk memberikan sejumlah uang atau dikenal juga sebagai biaya angkut dan menerima hak agar barang yang dikirimkannya sampai di tempat tujuan yang telah disepakati dalam keadaan selamat. Selain itu hak - hak lain yang dapat diterima oleh pengangkut adalah Perusahaan Angkutan Umum berhak untuk menerima uang sebagai biaya tambahan atas barang barang yang telah disimpan atau tidak diambil sesuai dengan perjanjian awal pengangkutan dan jika terdapat pihak pengirim barang maka tentu akan ada juga pihak pengangkut. Kewajiban lainnya yang juga harus dipenuhi oleh pengirim barang selain kewajiban utama seperti yang telah dibahas sebelumnya adalah untuk menyerahkan barang-barang yang akan dikirim kepada pengangkut untuk diangkut, membungkus barang-barang yang akan dikirim dengan benar dan tepat, serta memberikan daftar barangbarang yang akan dikirim untuk di angkut kepada pihak pengangkut. Dalam hal adanya kewajiban tentu akan terdapat hak juga sebagai timbal balik atas kewajiban yang sudah dilakukan untuk itu hak pengirim barang adalah mendapat jaminan bahwa barang-barangnya akan diangkut dan sampai ke tujuan dengan selamat, serta memperoleh pembayaran ganti rugi jika pengangkut wanprestasi. 
Hukum pengangkutan merupakan bagian dari hukum dagang yang termasuk dalambidang hukum perdata. Dilihat dari segi susunan hukum normatif, hukum perdata merupakan sub sistem tata hukum nasional. Jadi hukum dagang atau perusahaan termasuk dalam subsistem tata hukum nasional. Dengan demikian, hukum pengangkutan adalah bagian dari subsistem hukum nasional. Adapun tujuan dari pengangkutan adalah proses perpindahan barang dari tempat pemberangkatan ke tempat tujuan yang telah disepakati dengan keadaan selamat yang bertujuan untuk menambah daya guna barang dan menambah nilai barang tersebut. Kemudian fungsi dari pengangkutan adalah proses perpindahan barang dari suatu tempat ke tempat yang lain atau orang dari suatu tempat ke tempat lain yang bertujuan untuk menambah daya guna barang atau menambah nilai barang atau orang tersebut. Pada penjelasan sebelumnya telah khusus dijelaskan bahwa bertambahnya daya guna dan bertambahnhya nilai barang atau orang tersebut adalah tujuan utama dari diadakannya suatu pengangkutan, artinya apabila daya guna barang tersebut dan nilai barang tersebut pada tempat tujuan yang baru tersebut tidak mengalami kenaikan, maka tidak perlu diadakan pengangkutan. Dalam bidang pemerintahan, politik, sosial, dan pendidikan fungsi pengangkutan sebagaimana yang telah dijelaskan juga berlaku, dengan kata lain fungsi pengangkutan tersebut tidak hanya berlaku dalam dunia perdagangan saja. ${ }^{5}$ Dari segi hukum, khususnya hukum perjanjian, pengangkutan merupakan perjanjian timbal balik antara pengangkut dan pengirim barang atau penumpang dimana pihak pengangkut mengikatkan diri untuk menyelenggarakan pengangkutan barang atau orang ke suatu tempat tujuan tertentu, dan pihak pengirim barang atau penumpang mengikatkan diri pada ongkos pembayaran angkutannya. Di dalam perjanjian pengangkutan terlibat dua pihak, yaitu

5 H. M. N. Purwosutjipto, Pengertian Pokok Hukum Dagang Indonesia (Jakarta: Djambatan, 2008), hal. 2 
pengangkut dan pengirim barang atau penumpang. ${ }^{6}$ Salah satu jenis pengangkutan yang sedang berkembang saat ini adalah pengangkutan barang dengan jalur darat, mengirim barang dari suatu tempat ke tempat lainnya sehingga muncul perusahan jasa pengiriman barang yaitu PT. Birotika Semesta DHL Express yang merupakan perusahan pengangkut pengiriman barang milik swasta yang bergerak dibidang jasa. Perusahaan ini didirikan pada tahun 1969 di San Francisco lalu pada tahun 2002 dilakukan ekspansi jaringan ke wilayah Asia dalam bentuk Joint Venture. Faktor yang cukup banyak mempengaruhi perkembangan yang cukup pesat di bidang pengangkutan barang jalur darat adalah sektor bisnis melalui transaksi tanpa tatap muka secara langsung. Oleh karena banyaknya konsumen yang berminat menggunakan jasa pengiriman barang seperti DHL Express ini untuk mengirimkan barang ke tempat tujuan yang jaraknya jauh, menyebabkan semakin pentingnya jasa pengiriman barang dengan jenis seperti ini. Jasa kurir sebagai jasa pengiriman barang merupakan salah satu jasa yang dapat memenuhi kebutuhan manusia saat ini karena lebih efektif dan efisien. Selain itu jasa pengiriman barang ini juga menawarkan kepastian waktu barang sampai dan jaminan bagi pengguna jasa.

Menurut H.M.N Purwosutjipto, pihak-pihak dalam pengangkutan yaitu pengangkut dan pengirim. Pengangkut adalah orang yang mengikatkan diri untuk menyelenggarakan pengangkutan barang dan/atau orang dari suatu tempat ke tempat tujuan tertentu dengan selamat. Lawan dari pihak pengangkut adalah pengirim yaitu pihak yang mengikatkan diri untuk membayar uang angkutan dan juga memberikan muatan atau barang yang akan diangkut oleh pengangkut. ${ }^{7}$ Selama proses pengiriman barang kadang

${ }^{6}$ Ridwan Khairandy, Pengantar Hukum Dagang Indonesia I, (Yogyakarta, Gama Media, 2011), Hal. 200.

7 H.M.N Purwosutjipto., Pengertian Pokok Hukum Dagang Indonesia 3 Hukum Pengangkutan, (Jakarta, penerbit Djambatan, 1984), Hal. 2. 
tidak selalu berjalan dengan baik, misalnya kemungkinan terjadinya bencana, baik dari alam, sifat manusia maupun dari sifat barang itu sendiri. Terkadang terdapat kerusakan pada barang yang di kirim, bahkan sampai adanya kasus hilangnya barang. Sebagai contoh seperti kasus yang dialami oleh mantan penyanyi cilik Dea Imut yang mengirim barang satu unit kamera merek Canon tipe C 500 seharga $\mathrm{Rp}$ 225.000.000,00 (dua ratus dua puluh lima juta rupiah ).

Berdasarkan Kitab Undang Undang Hukum Dagang dalam Pasal 91 dijelaskan bahwa " Para pengangkut dan juragan kapal harus bertanggung jawab atas semua kerusakan yang terjadi pada barang-barang dagangan atau barang-barang yang telah diterima untuk diangkut, kecuali hal itu disebabkan oleh cacat barang itu sendiri, atau oleh keadaan diluar kekuasaan mereka atau oleh kesalahan atau kelalaian pengirim atau ekspeditur sendiri."

Selanjutnya berdasarkan Undang Undang Nomor 22 tahun 2009 tentang Lalu Lintas dan Angkutan Jalan dalam Pasal 188 dijelaskan bahwa Perusahaan Angkutan Umum wajib mengganti kerugian yang diderita oleh Penumpang atau pengirim barang karena lalai dalam melaksanakan pelayanan angkutan, bahkan dalam Pasal 199 disebutkan bahwa pelanggaran terhadap Pasal 188 dapat dikenakan sanksi pencabutan izin usaha dan Pasal 193 ayat (1) yang menjelaskan bahwa bahwa perusahaan pengangkut bertanggung jawab atas kerugian yang diderita oleh pengirim barang karena barang musnah, hilang, atau rusak akibat penyelenggaraan angkutan, kecuali terbukti bahwa musnah, hilang, atau rusaknya barang disebabkan oleh suatu kejadian yang tidak dapat dicegah atau dihindari atau kesalahan pengirim. 
Hal ini penting karena hanya hukum yang memiliki kekuatan untuk memaksa pelaku usaha untuk mentaatinya dan hukum juga memiliki sanksi yang tegas. Maka pemerintah memiliki kewajiban untuk melindingi pengguna jasa yang memiliki posisi lemah disamping ketentuan hukum yang kurang memadai.

Setelah diyakini adanya perbuatan lalai maka jumlah kerugian pun dapat dihitung. Setelah kerugian dihitung maka akan timbul pertanyaan apakah seluruh kerugian merupakan tanggung jawab dari perusahaan pengangkut. Hal ini jelas merupakan tanggung jawab sepenuhnya oleh perusahaan pengangkut, namun terdapat juga sedikit kesalah dari pengguna jasa yang mengirimkan barang dengan harga yang mahal hanya dengan menggunakan perusahaan pengangkut standar.

Dengan keadaan demikian, adalah sangat menarik untuk mengetahui secara lebih dekat lagi tentang pelaksanaan perjanjian dalam hukum pengangkutan ini terutama perihal bagaimana sebenarnya perjanjian pengangkutan tersebut disepakati. Banyak peristiwa hukum yang berkaitan dengan perjanjian pengangkutan khususnya yang berkaitan dengan tanggungjawab pihak jasa pengangkutan barang terhadap rusaknya atau hilangnya barang kiriman tersebut. Kenyataan yang ditemukan sering kali klaim yang diajukan oleh pengirim kurang ditanggapi oleh pihak perusahaan pengangkut sehingga terkadang timbul sengketa.

Pertanggung jawaban mengacu pada Undang - Undang Lalu Lintas dan Angkutan Darat dan apabila kelalaian tersebut berasal dari perusahaan pengangkut dalam pengertian bahwa orang yang dituju dan diberikan barang yang dikirimkan tidak sesuai dengan orang yang sebenarnya dituju, maka secara yuridis pengangkut harus bertanggung jawab dengan 
memberikan ganti kerugian kepada pengirim barang sesuai dengan kerugian yang nyata terhadap barang - barang yang hilang tersebut.

Pertama - tama apabila ada bukti - bukti yang dapat ditunjukan berkaitan dengan penyewaan kamera, seharusnya ditujukan pada saat proses litigasi di pengadilan kepada hakim sehingga hakim dapat menilai relevansi biaya sewa kamera tersebut apakah dapat dikabulkan sepenuhnya atau sebagian, tetapi untuk kerugian hilangnya kamera akibat kelalaian pegawai perusahaan pengangkut maka sudah wajib untuk diganti sesuai dengan nilai harga kamera tersebut dan jika ada kerugian lain tentunya bisa dimintakan juga.

Tetapi menurut Prof. Amad sudiro dilihat dari hasil putusan pengadilan kelihatannya hakim hanya fokus pada nilai riil dari kamera tersebut sementara kerugian lainnya tidak dijadikan pertimbangan apalagi nilainya lebih besar berkali lipat. Sebenarnya dengan keadaan yang menungu proses hukum selama itu seharusnya pengirim barang bisa saja dimintakan sewa kamera dengan persetujuan dengan perusahaan pengangkut dengan alasan pengirim barang sangat membutuhkan kamera tersebut karena apabila tidak, dapat menggagu aktifitas profesi dari pengirim barang. Seharusnya hal ini menjadi bahan pertimbangan hakim walaupun mungkin nilai nya tidak sebesar nilai yang tercantum pada tuntutan karena hilangnya alat yang vital untuk menunjang aktifitas profesi pihak pengirim barang yang dirugikan.

Karena putusan tersebut sudah incracht dan tidak dapat dilakukan upaya hukum lebih lanjut maka kasus ini tentunya dapat menjadi proses pembelajaran artinya dari sisi hakim harus lebih cermat dan lebih mempertimbangkan kerugian yang dialami oleh pengirim barang yang berdampak pada kerugian lain yang pada akhirnya membuat aktifitas rutin profesi pengirim barang menjadi terganggu. 
Dalam kasus ini hilang nya kamera merek Canon tipe C 500 milik Masayu Chairani dianggap sebagai peristiwa hukum yang menarik dan patut diangkat untuk dianalisis lebih lanjut. Selain karna nominal dari kamera yang cukup besar, juga karena perbuatan lalai oleh perusahaan pengangkut DHL Express yang memberikan barang tersebut kepada orang yang salah, sehingga Masayu Chairani mengalami kerugian meteril. Berdasarkan uraian tersebut maka penulis berinisiatif untuk melakukan penelitian dengan judul tanggung jawab perusahaan pengangkut DHL Express terhadap pengirim barang dalam pengangkutan dari Jakarta ke Malang Studi Putusan Pengadilan Nomor 733/Pdt.G/2017/PN.JKT.SEL.

\section{B. Perumusan Masalah}

Berdasarkan latar belakang yang diuraikan tersebut, permasalahan yang hendak diteliti dalam penulisan ini yaitu:

1. Bagaimana tanggung jawab perusahaan pengangkut DHL Express terhadap pengirim barang dalam pengangkutan dari Jakarta ke Malang?

2. Bagaimana Putusan Pengadilan Negeri Nomor 733/Pdt.G/2017/PN.JKT.SEL mengenai tanggung jawab perusahaan pengangkutan DHL Express terhadap pengirim barang dalam pengangkutan dari Jakarta ke Malang?

\section{Metode Penelitian}

Metode penelitian yang Penulis gunakan dalam proposal penulisan skripsi ini adalah penelitian hukum normatif. Penelitian hukum normatif adalah "suatu proses untuk menemukan suatu aturan hukum, prinsip-prinsip hukum, maupun doktrin-doktrin hukum untuk menjawab permasalahan hukum yang dihadapi". Suatu penelitian hukum, terdapat beberapa pendekatan. Guna mendapatkan informasi dari berbagai aspek mengenai isu yang dicoba untuk dicari jawabannya, maka Penulis menggunakan 
pendekatan undang-undang (statute approach). Pendekatan undang-undang adalah pendekatan yang dilakukan dengan menggunakan legislasi dan regulasi.

\section{PEMBAHASAN}

\section{A. Kasus Posisi}

Masayu Chairani adalah ibu dari mantan penyanyi cilik Dea Imut, Masayu Chairani sebagai pengguna jasa mengirim barang satu unit kamera merek Canon tipe C 500 seharga Rp 225.000.000,00 ( dua ratus dua puluh lima juta rupiah ). Kamera tersebut hendak dijual oleh pengguna jasa pada pembeli yang berada diluar kota. Sehubungan dengan domisili pengirim yang berada di kota jakarta dan domisili pembeli yang berada di kota Malang, Masayu Chairani selaku pengirim barang mengirimkan barang tersebut menggunakan jasa kurir angkutan barang darat dari DHL Express. Namun setelah melewati batas waktu pengiriman barang, pembeli tak kunjung menerima paket kiriman barang tersebut. Setelah ditelusuri oleh pihak pengirim barang ternyata barang tersebut diberikan kepada seseorang bernama Totok Suhadi di kantor DHL Express cabang Malang sementara seharusnya barang tersebut dikirimkan ke alamat yang telah disepakati sebelumnya. Alamat tersebut telah tertera di barang yang ingin dikrimkan untuk penerima atas nama Toto atau Suhadi, akan tetapi setelah barang tersebut sampai di DHL Express cabang kota Malang, pegawai DHL Express cabang Malang tersebut memberikan barang tersebut kepada seseorang yang datang ke kantor DHL Express tersebut dan mengaku bahwa barang tersebut adalah barang yang dikirmkan untuknya. Orang dengan nama Totok Suhadi tersebut mengambil barang tersebut dengan jaminan 
memberikan fotocopy KTP, setelah pengirim barang menyadari adanya kesalahan penerimaan barang, dilakukan penyelidikan terhadap KTP tersebut yang ternyata KTP tersebut adalah KTP palsu. Pihak pengirim barang baru menyadari bahwa barang yang dikirimkan tidak sampai pada penerima barang yang semestinya setelah penerima barang yang seharusnya menanyakan keberadaan barang tersebut kepada Masayu Chairani.

Selanjutnya pihak pengirim barang meminta pertanggung jawaban atas kelalaian pengiriman barang kepada pihak perusahaan pengangkut, namun keluhan pengirim barang tak kunjung ditindak lanjuti. Hal ini membuat Masayu Chairani terpaksa mengambil jalur hukum untuk menyelesaikan perkara tersebut dan menuntut pertanggung jawaban serta ganti rugi atas wanprestasi yang telah dilakukan oleh perusahaan pengangkut. Jalur hukum dipilih oleh penggugat sebab kerugian yang dialami oleh pengirim barang cukup besar dengan nominal yang cukup fantastis. Selain kamera canon tipe C 500 denga harga dua ratus dua puluh lima juta, pengirim barang juga harus mengeluarkan biaya yang cukup besar selama hilangnya kamera tersebut karena tuntutan pekerjaan yang mengharuskan pengirim barang untuk menyewa kamera dengan harga tujuh juta rupiah per hari selama tujuh bulan yang apa bila di jumlahkan total pengeluaran yang harus dikeluarkan oleh pihak pengirim barang untuk menyewa kamera pengganti mencapai nominal lebih dari satu milliyar rupiah, hal ini dapat terjadi lantaran profesi pengirim barang adalah mantan artis cilik Dea Anissa yang sekarang berprofesi sebagai pemain film sehingga tuntutan pekerjaan mengharuskan pengirim barang untuk menyewa kamera.

Sehubungan dengan pertimbangan - pertimbangan atas kerugian yang sangat besar, pihak pengirim barang selain menuntut ganti rugi atas kamera yang hilang dan biaya pengiriman barang ke kota Malang, pengirim barang 
juga menuntut ganti rugi atas penyewaan kamera yang harus dilakukan karena hilangnya kamera tersebut.

\section{B. Tanggung Jawab Perusahaan Pengangkut DHL Express Terhadap Pengirim Barang dalam Pengangkutan dari Jakarta ke Malang.}

Berawal dari hubungan saling membutuhkan antara seorang pengirim barang yaitu Massayu Chairani yang membutuhkan jasa pengiriman dengan sebuah perusahaan pengangkutan yang menyediakan jasa pengiriman barang yaitu DHL Express maka akan menimbulkan suatu perjanjian pengangkutan. Berdasarkan hasil wawancara Profesor Martono sebagai ahli dalam bidang hukum transportasi berpendapat suatu perjanjian antara pengangkut dan penumpang atau pengirim barang dimana penumpang atau pengirim barang memiliki kewajiban untuk memberikan biaya angkut sebagai bentuk imbalan bagi pengangkut juga berlaku kebalikannya pengangkut wajib mengangkut penumpang atau barang dengan selamat sampai tempat tujuan, karena itu apabila tidak selamat maka pengangkut bertanggung jawab, untuk itu dalam studi kasus yang sedang dibahas perusahaan pengangkut DHL Express haruslah bertanggung jawab atas ganti rugi kerugian yang dialami pengirim barang Massayu Chairani akibat dilanggarnya perjanjian pengangkutan barang yang seharusnya dikirimkan ke alamat yang disepakati.

Selain itu menurut ahli hukum transportasi Prof. Martono sebagai narasumber dalam kasus pelanggaran perjanjian pengangkutan antara Massayu Chairani dengan DHL Express ini terkait sangat erat dengan hukum perdata terikat melalui perjanjian dalam hal perjanjian pengangkutan antara perusahaan pengangkut DHL Express dengan pihak pengirim barang yaitu Massayu Chairani. Pengirim barang yang hendak mengirimkan barang berupa kamera bermaksud untuk menjual kamera tersebut kepada seorang pembeli di Malang atas nama Totok / Suhadi, namun kamera tersebut diberikan kepada orang lain yang mengklaim bahwa barang tersebut 
dikirmkan untuknya di DHL Express cabang kota Malang. Tidak sampainya barang tersebut dengan selamat sampai tujuan yang disepakati merupakan tindakan lalai yang dilakukan oleh pegawai DHL Express untuk itu perusahaan pengangkut haruslah memberikan gantu kerugian yang dialami pengirim barang sebagai bentuk tanggung jawab karena pelanggaran terhadap perjanjian pengangkutan yang telah disepakati. Oleh sebab itu para pihak yaitu DHL Express selaku perusahaan pengangkut dan Massayu Chairani selaku pengirim barang perlu memperhatikan pasal yang berkaitan dengan hukum perjanjian yang tercantum dalam hukum perdata yaitu pada Pasal 1320 KUH Perdata yang berisi syarat sah perjanjian. Syarat sah suatu perjanjian yang tercantum dalam Pasal 1320 KUH Perdata adalah :

1. Adanya Kesepakatan Kehendak

Dengan syarat kesepakatan kehendak dimaksudkan agar suatu kontrak dianggap sah oleh hukum, kedua belah pihak mesti ada kesesuaian pendapat tentang apa yang diatur oleh kontrak tersebut. Dalam perjanjian pengangkutan antara Massayu Chairani dengan perusahaan pengangkut DHL Express telah disepakati perjanjian pengakutan yang dapat dibuktikan dengan adanya resi pengiriman barang yang dikeluarkan oleh perusahaan pengangkut DHL Express.

\section{Kecakapan}

Syarat cakap melakukan perbuatan hokum maksudnya adalah bahwa pihak yang melakukan kontrak haruslah orang yang oleh hukum memang berwenang membuat kontrak tersebut. Sebagaimana pada Pasal 1330 KUH Perdata menentukan bahwa setiap orang adalah cakap untuk membuat perikatan, kecuali undang-undang menentukan bahwa ia tidak cakap. Mengenai orang-orang yang tidak cakap untuk membuat perjanjian dapat kita temukan dalam Pasal 1330 KUH Perdata. Massayu Chairani selaku pengirim barang dan perusahaan pengangkut DHL Express telah memenuhi syarat kecakapan tersebut sesuai dengan peraturan yang tertera dalam perundang - undangan. 


\section{Perihal Tertentu}

Dengan syarat perihal tertentu dimaksudkan bahwa suatu kontrak haruslah berkenaan dengan hal yang tertentu, jelas dan dibenarkan oleh hukum. Mengenai hal ini dapat kita temukan dalam pasal 1332 ddan1333 KUH Perdata. Perihal tertentu yang dimaksudkan dalam pembahasan studi kasus ini adalah hal - hal yang bersangkutan dengan pengiriman barang dari Jakarta ke Malang yang dilakukan oleh Massayu Chairani selaku pihak pengirim barang dengan perusahaan pengangkut DHL Express sebagai penyedia jasa angkut.

4. Kausa yang Diperbolehkan (halal)

Maksudnya adalah bahwa suatu kontrak haruslah dibuat dengan maksud / alasan yang sesuai hukum yang berlaku. Jadi tidak boleh dibuat kontrak untuk melakukan hal-hal yang bertentangan dengan hukum. Dan isi perjanjian tidak dilarang oleh undang-undang atau tidak bertentangan dengan kesusilaan / ketertiban umum (Pasal 1337 KUH Perdata), dapat dibuktikan dengan peraturan perundangan-undangan yang memperbolehkan perjanjian pengangkutan barang tepatnya diatur dalam Undang - Undang Nomor 22 tahun 2009, sehingga perjanjian pengangkutan barang dari Jakarta ke Malang antara Massayu Chairani dengan perusahaan pengangkut DHL Express memenuhi syarat yang halal. Selain itu Pasal 1335 KUH Perdata juga menentukan bahwa suatu perjanjian yang dibuat tanpa sebab atau dibuat karena suatu sebab yang palsu atau terlarang adalah tidak mempunyai kekuatan hukum, dalam studi kasus ini sangat jelas diterangkan bahwa sebab perjanjian pengangkutan barang ini dilakukan adalah keadaan saling membutuhkan untuk itu dapat dikatakan bahwa perjanjian pengangkutan ini dibuat dengan sebab yang jelas dan tentunya memiliki kekuatan hukum.

Dilihat dari sudut pandang hukum perjanjian maka seluruh syarat sah nya suatu perjanjian yang dalam hal kasus ini adalah perjanjian 
pengangkutan telah sepenuhnya terpenuhi dan dapat dipastikan memiliki kekuatan hukum. Untuk itu dengan adanya kekuatan hukum yang melindungi perjanjian pengangkutan barang dari Jakarta ke Malang antara Massayu Chairani dengan DHL Express. Apabila perjanjian pengangkutan barang tersebut dilanggar dalam arti barang yang dikrimkan tidak selamat sampai di alamat yang disepakati dengan tepat waktu, maka peristiwa pelanggaran ini dapat dikatakan sebagai wanprestasi dan harus dipertanggung jawabkan karena menimbulkan kerugian bagi salah satu pihak yang melakukan perjanjian pengangkutan. Dalam Pasal 191 UndangUndang Nomor 22 tahun 2009 dijelaskan bahwa perusahaan pengangkutan harus bertanggung jawab atas ganti rugi atas perbuatan lalai yang dilakukan oleh orang yang bekerja pada perusahaan pengangkutan tersebut, juga disebutkan dalam Pasal 91 Kitab Undang Undang Hukum Dagang dijelaskan bahwa dalam halnya pertanggungan barang-barang yang dikirimkan melalui daratan, si penanggungan juga bertanggung jawab untuk kerusakan dan kerugian yang diterbitkan karena salahnya atau kecuranganya orang-orang yang ditugaskan dengan penerimaan pengangkutan dan penyerahan barang-barang yang diangkut itu. Dengan terjadinya peristiwa tersebut, maka dapat disebutkan bahwa perusahaan pengangkutan melakukan kelalaian dan telah merugikan pengirim barang yang dalam hal ini adalah Massayu Chairani, sehingga hak si pengirim barang tersebut telah dirampas oleh perusahaan pengangkutan dan perusahaan pengangkut tidak memenuhi kewajibannya, maka dapat dikatakan perusahaan pengangkutan tersebut telah melakukan wanprestasi sebagaimana diatur dalam Pasal 1243 Kitab Undang-Undang Hukum Perdata.

Tindakan wanprestasi yang dilakukan oleh perusahaan pengangkut DHL Express tersebut pada akhirnya akan menimbulkan pelanggaran terhadap dasar-dasar kewajiban perusahaan pengangkut dan juga sekaligus melanggar dasar hak-hak pengirim barang yaitu mendapat jaminan bahwa 
barang-barangnya akan diangkut dan sampai ke tujuan dengan selamat. Melalui pembahasan akan timbul fakta-fakta bahwa kewajiban perusahaan pengangkut DHL Express tidak terpenuhi karena barang yang seharusnya dikirimkan ke alamat yang dituju tidak dilaksanakan sesuai kesepakatan perjanjian pengangkutan, yang mengakibatkan hilangnya barang tersebut. Dengan hilangnya barang yang seharusnya dikirimkan dari Jakarta ke Malang tersebut maka hal ini menimbulkan kerugian bagi pihak pengirim barang yaitu Massayu Chairani bahkan kerugian ini menyebabkan terganggunya aktivitas profesi dari si pengirim barang. Kerugian yang dialami oleh Massayu Chairani ini juga dapat dikatakan tidak sesuai dengan dasar-dasar hak pengirim barang karena barang yang dikirimkan tidak sampai ditujuan dengan selamat.

Tidak hanya pengirim barang yang memiliki hak, perusahaan pengangkut pun memiliki hak yaitu untuk menerima bayaran berupa uang atas jasa pengiriman barang, pada kasus ini perusahaan pengankut telah menerima hak nya untuk dibayar namun tidak melaksanakan kewajibannya sampai tuntas. Maka dari itu akibat adanya ketidak adilan antara pihak pengangkut dengan pihak pengirim barang akan menimbulkan kelalaian yang dapat dianggap sebagai wanprestasi sementara pihak pengirim barang telah memenuhi kewajiban nya untuk membayar jasa angkut pengiriman barang dari Jakarta ke Malang sesuai dengan ketentuan yang berlaku. Dengan adanya ketimpangan hak yang seharusnya diterima oleh pengirim barang maka perusahaan pengangkut DHL Express harus bertanggung jawab atas kerugian yang diderita pengirim barang akibat tidak terpenuhinya hak -hak pengirim barang.

Tanggung jawab perusahaan pengangkut dalam Pasal 188 Undang Undang Nomor 22 tahun 2009 tentang Lalu Lintas dan Angkutan Jalan dalam dijelaskan bahwa Perusahaan Angkutan wajib mengganti kerugian yang diderita oleh Penumpang atau pengirim barang karena lalai dalam 
melaksanakan pelayanan angkutan. Selain itu jugta dijelaskan dalam Pasal 193 bahwa perusahaan pengangkut bertanggung jawab atas kerugian yang diderita oleh pengirim barang karena barang musnah, hilang, atau rusak akibat penyelenggaraan angkutan, kecuali terbukti bahwa musnah, hilang, atau rusaknya barang disebabkan oleh suatu kejadian yang tidak dapat dicegah atau dihindari atau kesalahan pengirim. Dalam hal ini perlindungan terhadap pengguna jasa pengiriman barang sangat dibutuhkan oleh pihak pengirim barang seperti Massayu Chairani yang telah dirugikan akibat kelalaian yang dilakukan oleh perusahaan pengangkut , pembahasan ini diperkuat dengan pendapat salah satu narasumber yang merupakan dosen hukum transportasi Prof. Amad Sudiro yang menyatakan bahwa pertanggung jawaban mengacu pada Undang - Undang Lalu Lintas dan Angkutan Darat dan apabila kelalaian tersebut berasal dari perusahaan pengangkut dalam pengertian bahwa orang yang dituju dan diberikan barang yang dikirimkan tidak sesuai dengan orang yang sebenarnya dituju, maka secara yuridis pengangkut harus bertanggung jawab dengan memberikan ganti kerugian kepada pengirim barang sesuai dengan kerugian yang nyata terhadap barang - barang yang hilang tersebut.

Berkaca dari prinsip - prinsip Tanggung jawab, prinsip tanggung jawab untuk selalu bertanggung jawab (presumption of liability), tindak kelalaian dalam pengiriman barang oleh DHL Express sesuai dengan prinsip tanggung jawab tersebut, sebab kesalahan dilakukan oleh pegawai DHL Express cabang kota Malang yang memberikan paket barang yang seharusnya dikirmkan ke alamat dituju yang telah disepakati pada seseorang yang mengklaim bahwa paket barang tersebut adalah miliknya dengan hanya memberikan KTP palsu sebagai jaminan untuk mengambil barang. Maka perusahaan pengangkut hasrulah bertanggung jawab atas wanprestasi tersebut sampai dengan dapat dibuktikannya bahwa ia tidak bersalah. 
Tujuan dari dibentuknya pasal-pasal dari berbagai Undang-Undang yang melindungi hak-hak pengguna jasa pengiriman barang adalah untuk menjamin barang yang dikirimkan sampai dengan selamat dalam keadaan utuh dan tepat waktu sesuai dengan perjanjian pengangkutan barang yang sudah ada sebelumnya. Kesepakatan antara pihak pengangkut yang sepakat untuk mengikatkan diri denagn perusahaan pengangkut untuk melakukan angkutan barang atau penumpang dari suatu tempat keberangkatan ke tempat tujuan tertentu yang telah disepakati sebelumnya dengan selamat merupakan sesuatu yang disebut dengan perjanjian pengangkutan, sementara itu di sisi lain pengirim barang yang telah sepakat untuk mengikatkan diri dengan perjanjian pengangkutan tersebut wajib memberikan uang sebagai biaya angkut.

Teori perjanjian secara umum haruslah terpenuhi, kemudian dari uraian tersebut penulis dapat menyimpulkan bahwa perjanjian pengangkutan barang yang dilakukan oleh Massayu Chairani menggunakan jasa pengangkutan DHL Express dari Jakarta ke Malang telah memenuhi syarat - syarat sah perjanjian pengangkutan barang sebagaimana diatur dalam Pasal 1320 KUH Perdata. Namun perjanjian tersebut dilanggar oleh perusaahan pengangkut karena barang yang dikirimkan tersebut tidak sampai pada tujuan dengan selamat dan tepat waktu, sehingga menimbulkan kerugian yang cukup besar bagi pengirim barang kareana hak - hak pengirim barang yang seharusnya diterima Massayu Chairani tidak terpenuhi melainkan diabaikan oleh perusahaan pengangkut DHL Express sebagai penyedia jasa angkut yang melakukan pelanggaran perjanjian angkutan atau dapat dikatakan sebagai tindakan wanprestasi.

Penulis tidak melihat adanya iktikad baik untuk bertanggung jawab dari perusahaan pengangkut DHL Express, dengan demikian perusahaan pengangkut DHL Express haruslah bertanggung jawab penuh atas seluruh kerugian yang diderita oleh pengirim barang akibat kelalaian atau 
wanprestasi yang ditimbulkan oleh DHL Express baik kerugian materi riil secara nyata maupun kerugian - kerugian lain yang turut disebabkan oleh hilangnya barang tersebut. Pendapat penulis juga didukung dengan keterangan para ahli hukum transportasi yaitu Prof. Martono dan Prof. Amad Sudiro yang juga mengatakan bahwa tindakan wanprestasi yang dilakukan oleh perusahaan pengangkut harus dipertanggung jawabkan secara penuh kepada pengirim barang karena menyebabkan kerugian yang cukup besar dan mengganggu aktivitas rutin profesi pihak pengirim barang dalam hal yang dimaksud adalah hilangnya barang berupa kamera yang merupakan alat vital sebagai penunjang profesi pihak pengirim barang.

C. Putusan Pengadilan Negeri Nomor 733/Pdt.G/2017/PN.JKT.SEL Mengenai Tanggung Jawab Perusahaan Pengangkutan DHL Express Terhadap Pengirim Barang dalam Pengangkutan dari Jakarta ke Malang.

Dalam upaya Undang - Undang memberikan perlindungan hukum sebagai alat penegak hukum tentunya diperlukan bantuan dari pihak pemerintah sebagai aparatur penegak hukum, upaya yang dilakukan pengirim barang Massayu Chairani sebagai pihak yang dirugikan untuk menuntut keadilan adalah melalui jalur hukum dengan mengajukan tuntutan ke Pengadilan Negeri Jakarta Selatan terhadap perusahaan pengangkut DHL Express atas tindakan wanprestasi atas pelanggaran perjanjian pengangkutan yang dilakukan perusahaan tersebut.

Pada awalnya Masayu Chairani sebagai pengguna jasa mengirim barang satu unit kamera merek Canon tipe C 500 seharga Rp 225.000.000,00 ( dua ratus dua puluh lima juta rupiah ). Kamera tersebut hendak dijual oleh 
pengguna jasa pada pembeli yang berada diluar kota. Sehubungan dengan domisili pengirim yang berada di kota jakarta dan domisili pembeli yang berada di kota Malang, Masayu Chairani selaku pengirim barang mengirimkan barang tersebut menggunakan jasa kurir angkutan barang darat dari DHL Express. Namun setelah melewati batas waktu pengiriman barang, pembeli tak kunjung menerima paket kiriman barang tersebut. Setelah ditelusuri oleh pihak pengirim barang ternyata barang tersebut diberikan kepada seseorang bernama Totok Suhadi di kantor DHL Express cabang Malang sementara seharusnya barang tersebut dikirimkan ke alamat yang telah disepakati sebelumnya. Alamat tersebut telah tertera di barang yang ingin dikrimkan untuk penerima atas nama Toto atau Suhadi, akan tetapi setelah barang tersebut sampai di DHL Express cabang kota Malang, pegawai DHL Express cabang Malang tersebut memberikan barang tersebut kepada seseorang yang datang ke kantor DHL Express tersebut dan mengaku bahwa barang tersebut adalah barang yang dikirmkan untuknya. Orang dengan nama Totok Suhadi tersebut mengambil barang tersebut dengan jaminan memberikan fotocopy KTP , setelah pengirim barang menyadari adanya kesalahan penerimaan barang, dilakukan penyelidikan terhadap KTP tersebut yang ternyata KTP tersebut adalah KTP palsu. Pihak pengirim barang baru menyadari bahwa barang yang dikirimkan tidak sampai pada penerima barang yang semestinya setelah penerima barang yang seharusnya menanyakan keberadaan barang tersebut kepada Masayu Chairani. Selanjutnya pihak pengirim barang meminta pertanggung jawaban atas kelalaian pengiriman barang kepada pihak perusahaan pengangkut, namun keluhan pengirim barang tak kunjung ditindak lanjuti.

Hal ini membuat Masayu Chairani terpaksa mengambil jalur hukum untuk menyelesaikan perkara tersebut dan menuntut pertanggung jawaban serta ganti rugi atas wanprestasi yang telah dilakukan oleh perusahaan pengangkut, dengan tuntutan ganti rugi atas hilangnya kamera merek Canon tipe C 500 seharga Rp 225.000.000,00 ( dua ratus dua puluh lima juta rupiah 
), ganti rugi atas biaya angkut sebesar Rp 529.000,00 ( lima ratus dua ratus dua puluh sembilan ribu rupiah) dan ganti rugi sewa kamera yang harus dilakukan akibat hilangnya kamera tersebut sebesar kurang lebih $\mathrm{Rp}$ 500.000.000,00 ( lima ratus juta rupiah). Jalur hukum dipilih oleh penggugat sebab kerugian yang dialami oleh pengirim barang cukup besar dengan nominal yang cukup fantastis. Selain kamera canon tipe C 500 dengan harga dua ratus dua puluh lima juta, pengirim barang juga harus mengeluarkan biaya yang cukup besar selama hilangnya kamera tersebut karena tuntutan pekerjaan yang mengharuskan pengirim barang untuk menyewa kamera dengan harga kurang lebih Rp 500.000.000,00 (lima ratus juta rupiah), hal ini dapat terjadi lantaran profesi pengirim barang adalah mantan artis cilik Dea Anissa yang sekarang berprofesi sebagai pemain film sehingga tuntutan pekerjaan mengharuskan pengirim barang untuk menyewa kamera. Namun berdasarkan hasil putusan hakim menurut dosen hukum transportasi Prof. Amad Sudiro hasil putusan pengadilan kelihatannya hakim hanya fokus pada nilai riil dari kamera tersebut sementara kerugian lainnya tidak dijadikan pertimbangan apalagi nilainya lebih besar berkali lipat. Sebenarnya dengan keadaan yang menungu proses hukum selama itu seharusnya pengirim barang bisa saja dimintakan sewa kamera dengan persetujuan dengan perusahaan pengangkut dengan alasan pengirim barang sangat membutuhkan kamera tersebut karena apabila tidak, dapat menggagu aktifitas profesi dari pengirim barang.

Isi dari putusan hakim pengadilan negeri Jakarta Selatan mengabulkan gugatan Massayu Chairani untuk sebagian, menyatakan bahwa perbuatan Perusahaan Pengangkut DHL Express yang tidak mengantarkan secara langsung barang yang harus dikirimkan ke alamat Jalan Papa Biru 3 Nomor 58, Kelurahan Tulus Rejo, Kecamatan Lowokwaru, Kodya Malang, Provinsi Jawa Timur atas nama Suhadi alias toto adalah wanprestasi, menghukum Perusahaan Pengangkut DHL Express untuk membayar ganti rugi penggantian satu unit kamera Canon DSLR Full Set, menghukum Perusahaan 
Pengangkut DHL Express dengan membayar pada Massayu Chairani kerugian pembayaran jasa pengiriman paket dengan harga lima ratus dua puluh sembilan riu tiga ratus lima puluh delapan rupiah, dan menghukum Perusahaan Pengangkut DHL Express untuk membayar biaya perkara sejumlah enam ratus dua puluh enam ribu rupiah.

Hasil putusan Pengadilan Negeri Nomor 733/Pdt.G/2017/PN.JKT.SEL yang memutus tuntutan pengirim barang dikabulkan atas sebagian, namun kerugian yang dialami pengirim barang masih cukup besar sebab tuntutan ganti rugi atas sewa kamera selama barang yang dikirimkan (kamera) hilang tidak dikabulkan. Wanprestasi atas kelalaian yang dilakukan oleh perusahaan pengangkut tidak dipertanggung jawabkan sepenuhnya sementara kelalaian yang dilakukan oleh perusahaan pengangkut adalah mutlak kesalahan. Putusan yang diputus oleh hakim dianggap sangat memberatkan pihak pengirim barang sebagai pihak yang dirugikan, menurut pendapat Profesor Martono sebagai Ahli hukum Transportasi kelalaian yang dilakukan oleh perusahaan pengangkut wajib melakukan ganti rugi atas kesalahannya apabila barang tidak sampai dengan selamat di tujuan yang disepakati. Sementara pendapat penulis sendiri juga sangat setuju dengan pendapat Prof. Amad Sudiro yang menganggap bahwa hakim kurang cermat dan tidak memperhatikan kerugian-kerugian lain selain kerugian kamera secara nyata padahal kerugian-kerugian lain tersebut dapat menyebabkan terganggungnya aktivitas rutin yang berkaitan dengan profesi pihak pengirim barang. Selain itu hakim juga kurang mempertimbangkan kerugian besar yang dialami pihak pengirim barang akibat lamanya proses hukum yang membuat pengirim barang barang terpaksa menyewa kamera pengganti demi kelancaran proses rutinitas profesi pihak pengirim barang yang tentunya dibuktikan dengan bukti-bukti nyata yang ditunjukan oleh pihak pengirim barang pada saat proses litigasi pada saat persidangan. 
Berdasarkan fakta-fakta yang menjelaskan studi kasus yang diangkat oleh penulis, dengan menimbang kerugian-kerugian yang dialami oleh pihak pengirim barang baik secara materi maupun kerugian lain, apa lagi kerugian materi yang nyata dialami oleh pengirim barang memiliki nominal yang cukup besar maka penulis tidak setuju dengan putusan pengadilan yang diputus oleh hakim Pengadilan Negeri Jakarta Selatan karena dinilai memberatkan posisi pengirim barang yang hak-hak nya tidak dipenuhi seluruhnya dan masih mengalami kerugian yang tidak diganti oleh perusahaan pengangkut DHL Express karena tuntutan nya yang hanya dikabulkan sebagian oleh hakim.

\section{PENUTUP}

\section{A. Kesimpulan}

1. Perusahaan pengangkut DHL Express tidak bertanggung jawab secara penuh terhadap kerugian yang dialami oleh pihak pengirim barang yaitu Massayu Chairani yang melakukan perjanjian pengangkutan barang dari Jakarta ke Malang dengan perusahaan pengangkut DHL Express telah dirugikan akibat pelanggaran perjanjian pengangkutan barang atau dapat disebut juga dengan wanprestasi yang dilakukan oleh DHL Express karena tidak sesuai dengan Pasal 91 KUHD serta Undang Undang Nomor 22 tahun 2009 tentang Lalu Lintas dan Angkutan Jalan dalam Pasal 188 dan Pasal 193 ayat (1).

2. Dalam Putusan Pengadilan Negeri Nomor 733/Pdt.G/2017/PN.JKT.SEL mengenai tanggung jawab perusahaan pengangkutan DHL Express terhadap pengirim barang dalam pengangkutan dari Jakarta ke Malang yang memutus untuk tidak mengabulkan sepenuhnya ganti rugi atas kerugian yang dialami oleh 
pihak pengirim barang yaitu Massayu Chairani sementara kerugian tersebut bernilai cukup besar akibat tuntutan aktivitas profesi dari pengirim barang sendiri, hasil putusan ini dianggap kurang adil karena tidak sesuai dengan Pasal 91 KUHD serta Undang Undang Nomor 22 tahun 2009 tentang Lalu Lintas dan Angkutan Jalan dalam Pasal 188 dan Pasal 193 ayat (1) yang juga didukung dengan keterangan dari hasil wawancara dengan para ahli hukum transportasi.

\section{B. Saran}

1. Perusahaan pengangkut DHL Express sebaiknya bertanggung jawab penuh atas kelalaian pelanggaran perjanjian pengangkutan barang dari Jakarta ke Malang yang mengakibatkan baik kerugian riil secara materi maupun kerugian- kerugian lain yang menggangu kelancaran aktivitas profesi pengirim barang yaitu Massayu Chairani sesuai dengan ketentuan dalam KUHD Pasal 91 serta Undang Undang Nomor 22 tahun 2009 tentang Lalu Lintas dan Angkutan Jalan dalam Pasal 188 dan Pasal 193 ayat (1).

2. Putusan pengadilan seharusnya memutus dengan lebih cermat untuk mengabulkan tuntutan ganti rugi atas seluruhnya dari Massayu Chairani selaku pengirim barang yang telah dirugikan sesuai dengan Pasal 91 KUHD serta Undang Undang Nomor 22 tahun 2009 tentang Lalu Lintas dan Angkutan Jalan dalam Pasal 188 dan Pasal 193 ayat (1) yang juga didukung dengan keterangan dari hasil wawancara dengan para ahli hukum transportasi.

\section{E. DAFTAR PUSTAKA}

\section{A. Buku}


Adji, Sution Usman. Hukum pengangkutan indonesia. (Jakarta:PT Rinka Cipta, 1990).

Amirudin dan Zainal Asikin. Pengantar Metode Penelitian Hukum. (Jakarta: Raja Grafindo Persada, 2004).

ND, Mukti Fajar dan Yulianto Achmad. Dualisme Penelitian Hukum Normatif dan Empiris. (Yogyakarta: Pustaka Pelajar, 2017).

Khairandy, Ridwan. Pengantar Hukum Dagang Indonesia I. (Yogyakarta, Gama Media, 2011).

Kristiyanti, Celina Tri Siwi. Hukum Perlindungan Konsumen. (Jakarta,Sinar Grafika, 2008).

Marzuki, Peter Mahmud. Penelitian Hukum. (Jakarta: Kencana Prenada Media Group, 2013).

Muhammad, Abdul Kadir. Hukum Pengangkutan Darat, Laut, dan Udara. (Bandung: PT.Citra Aditya Bakti 1991).

Purwosutjipto, H. M. N. Pengertian Pokok Hukum Dagang Indonesia. (Jakarta: Djambatan, 2008).

, Pengertian Pokok Hukum Dagang Indonesia 3 Hukum Pengangkutan. (Jakarta, penerbit Djambatan, 1984).

Samsul, Inosentius. Perlindungan Konsumen Kemungkinan Penerapan Tanggung Jawab Mutlak. Cetakan ke-1. (Jakarta: Universitas Indonesia Fakultas Hukum Pascasarjana, 2004).

Shidarta. Hukum Perlindungan Konsumen Indonesia. Cetakan ke-1. (Jakarta: PT. Gasindo, 2000).

Hukum Perlindungan Konsumen Indonesia. Cetakan ke-3. (Jakarta: PT. Grasindo, 2006).

Shofie, Yusuf. Pelaku Usaha, Konsumen, dan Tindak Pidana Korporasi. (Jakarta:Ghalia Indonesia, 2002).

Subekti, R. Hukum Perjanjian. (Jakarta : PT.Intermessa, 2005).

Suharnok. Hukum Perjanjian. (Jakarta:Media, Jakarta, 2004).

Tjakranegara, Soegijatna. Hukum Pengangkutan Barang dan Penumpang. (Jakarta, PT.Rineka Cipta, 1995). 


\section{B. Undang-Undang}

Indonesia. Undang-Undang Nomor 22 Tahun 2009 tentang Lalu Lintas dan Angkutan Jalan.

\section{Jurnal}

Kantaatmadja, Komar. “Tanggung Jawab Profesional”. Jurnal Era Hukum Tahun III No. 10 (Oktober 1996).

Shofie, Yusuf. Product Liability Dalam Institusi Hukum Ekonomi Suatu Kajian Ius Constituendum, Jurnal Hukum Dan Pembangunan. No. 3 Tahun XXIX. Juli September 1999.

\section{Internet}

"Profil DHL Express" www.dhl.co.id diakses pada tanggal 20 April 2019.

\section{E. Kamus}

Pusat bahasa Departemen Pendidikan Nasional, Kamus Bahasa Indonesia, (Jakarta: Pusat Bahasa, 2008). 